\title{
DOES THE GRANTED ACCESS TO THE COURT AUTOMATICALLY GUARANTEE THE CITIZEN THE ACCESS TO JUSTICE?
}

\author{
Michal Mrva - Michal Krajčovič \\ Comenius University in Bratislava, Faculty of Law
}

\begin{abstract}
The authors examine the content of the terms access to the court and access to justice. These terms can be considered identical in a system based on the material rule of law (material legal state), that respects its principles. Social reality, sometimes, however, proves the opposite. The successfulness of ensuring (guaranteeing) the access to justice is determined, first and foremost, by the quality of the personal substrate of the judicial authorities - mainly judges themselves. The authors identify which personal characteristics are crucial in this regard. These include the judge's level of professionalism (due professional care), moral integrity and communication competence. In order to consider the judicial decision-making process as the process (procedure) leading to justice, all of these requirements must be met at the same time.
\end{abstract}

Key words: justice, court, Bangalore principles

Motto

Licet hoc iure contingat, tamen aequitas doctat.

Although it is happening according to the law, after all it requires politeness (justice).

Domitius Ulpianus $^{1}$

\section{THE ACCESS TO THE COURT IN COMPARISON WITH THE ACCESS TO JUSTICE}

Access to justice is by most people (therefore not just by lawyers or academics) automatically associated with the access to the court. But does one's right for the access to the court (art. no. 46 (1) of the Constitution of the Slovak Republic, further as "Constitution“) simultaneously guarantee the access to justice? If not, what requirements have to be met in order to consider these terms equal?

The successfulness of ensuring equality of the terms access to the court and access to justice is dependent on different requirements. In a system based on the rule of law (in theory) the mathematical symbol „= " may be put between these terms. The reason is the fact that justice is a function of the law (legal system $)^{2}$ and basic value as well, therefore the judge is legitimately expected to seek its fulfilment in the courtroom. When considering the contrary social reality in many cases, one should strengthen the desire and will to fulfil the principle of legal state and not abandon the belief in achieving it.

D.15,1,32,pr. REBRO, K.: Latinské právnické výrazy a výroky. Bratislava: OBZOR, 1984, p. 20 and 156. Supreme Administrative Court of the Czech republic, judgement 2 Afs/107/2007 of 23 January 2008. 
One must, however, take into account that the judge is a human being, thus naturally tempted to usurp the power and misuse it in order to satisfy a private interest at the expense of the interest of the general public. The judge (through his personal qualities) must therefore provide a guarantee, that the civil society will not remain disappointed in its trust in legal, legitimate and fair exercise of power by the state. ${ }^{3}$ Interpretation of law (legal texts) within the process of its application performed in breach of the requirement of professional diligence ${ }^{4}$ often leads to an unjust ruling. Although supported by sophisticated legal argumentation, an unfair decision cannot be convincing and capable of fulfilling the principle of legal certainty in the eyes of the general public. ${ }^{5}$ A ruling arbitrary or circumventing the law thus cannot be considered to be the result of the exercise of one's right for a fair trial (access to justice), although the access to the court, a public body acting on behalf of the state, was maintained.

The authors perceive the access to the court solely in terms of ensuring access to a judicial authority (public body), that will perform the subsumption of the factual findings in a certain case under the legal norm and afterwards set an authoritative discourse in a particular legal relationship or answer the raised legal question. On the other hand, access to justice is determined by the qualitative aspect of the process of application of law which is performed by the courts in the name of the state. The quality level of this legal procedure is mainly determined by the reflection of legal principles in the decision-making process, because otherwise the court's approach to law is formalistic, that is extremely unjust. Legal principles fulfil the reception function, fixing the societal values in the legal order in order to provide legal protection for these moral standards. ${ }^{6}$

One can afterwards accept and identify with the conclusion of J. Wintr, that the constitutional system of values, in a state based on the rule of law, must be taken into account during the interpretation of any legal norm. ${ }^{7}$

A firmly established guarantee of fairness and high standard of the decision-making process can be found (not only) in the advanced legal culture of the European continent. This guarantee is widely recognized as one of the most fundamental principles of constitutional orders of states belonging to this legal culture, that naturally falls within the material core of the their constitution. ${ }^{8}$ The mentioned principle is the principle of the independence of the judiciary, which includes coexisting guarantees of judicial independence (in organizational and functional terms ${ }^{9}$ ) and guarantees of independence of the judges themselves, acting on behalf of the judicial branch of state power.

Therefore the access to justice relies, first and foremost, on quality of the personal substrate of the judicial authorities represented mainly by judges themselves. The judge is an irreplaceable part of

3 This fact was known throughout the history. For instance, in the Gortyn law code, considered to be the oldest legislative text in Europe, the judge (dekastas) had to rule in accordance with justice and the main guarantees of the fairness of his rulings were his moral characteristics. VASILAKIS, A.: The Great Inscription of the law code of Gortyn. Heraklion: MYSTIS, 2007, pp. 78-79.

4 Professional diligence can be perceived as the standard of special skill and care which the judge may reasonably be expected to exercise towards the subjects of the proceedings.

5 One can take into account the words of the Roman lawyer and theoretician Iulius Paulus „In fraudem legis, facit, qui salvis verbis legis sententiameius circumvenit“ - REBRO, K.: Latinské právnické výrazy a výroky. Bratislava: OBZOR, 1984, p. 131.

6 The legal principle is (should be) an normative expression of a certain value. Afterwards the value is the explicit appellation of good and every value can be used for the purposes of forming a legal principle. MELZER, F.: Metodologie nalézání práva. Úvod do právní argumentace. 2nd ed. Praha: C. H. Beck, 2011, p. 53.

7 WINTR, J.: Metody a zásady interpretace práva. Praha: Auditorium, 2013, p. 136.

8 The argument whether the material core is explicit or implicit is, however, not relevant.

9 Or static and dynamic point of view. 
the judiciary and it is mainly up to his character and professionalism to guarantee, that by granting the access to the court a citizen is automatically and simultaneously granted the access to justice, regardless of the outcome of the proceeding.

\section{FULFILLING JUSTICE}

A certain consensus can be found both in the legal doctrine ${ }^{10}$ and judicial environment regarding the attributes of a judge's independence. The attributes include his professional level (further as "professionalism") and moral integrity. A righteous judge can only be an independent judge and thus the determinants of a judge's independence determine the fairness of his rulings and the actions taken. It needs to be pointed out, that rulings and actions taken (not only in exceptional cases) significantly interfere with one's human rights guaranteed by the constitution.

Nevertheless, justice may be granted only if the judge's behaviour in the courtroom, his way of communication with the parties of the proceeding (including the reasoning of the decision) and his attitude to any other person interested in the proceeding (e.g. witness) are conducted in a way which does not give rise to any doubts about the person of the judge as an „independent arbiter” trying to ensure justice in the case at hand. In this regard, the existence of the judge's communication competence, i.e. certain personal skill of the judge consisting in the ability to communicate during the proceedings and by rendering the judgment, is presupposed.

\subsection{Professionalism and moral integrity}

Under professionalism the authors understand the level of judge's expert knowledge in the field of law, his previous experience, as well as readiness to apply them. The guarantees of expert knowledge of a certain judge are represented by the undertaken professional judicial examination, required master's degree in law, the selection procedure etc. The appropriate level of expertise is required mainly in the area of the rule of law itself, interpretation of legal norms (advanced legal methodology) and legal reasoning (legal hermeneutics).

As a consequence of meeting all the mandatory requirements, the civil society legitimately presumes, that the application of law procedure will be carried out in accordance with due professional care (professional diligence as already stated). The content of the term professional care can be identified by the conjunction of the meanings of professional (adjective) and care (noun). Professional standardly means related to or connected with a certain profession. Under the term care one can generally understand all activities aimed at observing the good condition of something or observing the successful course of something. Due professional care of a judge is therefore the attention paid to the successful course of the judicial proceedings, enabling the judge to deliver a fair ruling as a result of the application of recent scientific knowledge in the field of law. The referred presumption is needed to be materially fulfilled in every single action taken by the judge, as it ensures the European standards of human rights protection, included in various international multilateral agreements.

10 Per exempla ČENTÉŠ, J. et al.: Trestné právo procesné. Všeobecná čast'. Šamorín: Heuréka, 2016, p. 88 or DRGONEC, J.: Ochrana ústavnosti Ústavným súdom Slovenskej republiky. Bratislava: EUROKÓDEX, 2010, p. 83. 
As a presumed expert in legal methodology, the judge has to decode the idea of the rational legislator ${ }^{11}$ standing above the legal norm that is prior to the norm from a comparative perspective from the view point of time. Each legal norm needs to be interpreted ${ }^{12}$ with a holistic approach to the legal system, in which the norm is incorporated. Objective law (legal order) cannot be understood solely as a summary of legal norms. Objective law includes both legal norms and the systematic bonds between them, because these internal bonds guarantee that legal order (or the legal state) will not fall into the state of chaos, regardless of its complexity and diversity. When the approach to a certain legal norm differs from the approach previously described, the interpreter (judge) can negate the true will of the legislator standing behind the written text of the norm and depart from the pathway of seeking justice. Teleological interpretation of the applicable legal norms always has to be taken into account before reaching a decision. This obligation is coherent with the model of ideology of legal and rational application of law, that is favoured in the conditions of a material legal state.

It has to be stated in this regard, that one can distinguish two types of cases - an easy (clear)case and hard case. ${ }^{13}$ The easy cases are governed by the rules clara non sunt interpretanda and interpretatio cessat in claris. ${ }^{14}$ The process of interpretation and subsequent application of law executed by the judge is more mechanical (automatic) in comparison with a hard case. In a hard case the legitimate answer to the question quid iuris? relies on the judge's creative approach to law, perceiving it in its necessary complexity. Textual interpretation of the applicable legal text does not hint the judge the fair decision ought to be rendered. Nevertheless, even a hard case must be decided in accordance with the true will of the rational legislator, while preserving the principle banning denegatio iustitiae. The judge has to find the fair decision through other methods of interpretation - mostly through teleological and authentic method of interpretation, which enable to unfold the true will of the rational legislation (either the historical legislator or the recent legislator). Mainly teleological interpretation enables the judge to identify, whether a particular decision (which is being considered) would be in accordance or in breach of the basic societal values, incorporated into the legal order in the form of legal principles.

It must be stated, that principles fulfil the rulemaking function as well. The legislator must therefore consider the principles (in relation to one another; proportionally to their importance for certain societal relationships) before formulating the legal norms, before formulating the text of the norm. No matter how strongly we perceive the legislator to be rational, even the legislative body causes errors and thus the legal norm may be contrary to the legal principle (basic societal value). A certain tension between these sources of law naturally occurs and it is up to the interpreter to interpret the norm in the way (in the legal state). When the tension between the applicable law (legal certainty) and basic societal values (e.g. Justice) is of extreme measures, the judge has to decide in accordance with the principles, which find their way into the process of legal interpretation through material-systematic method of interpretation. This method falls both under teleological method of

11 It is a basic assumption of the jurisprudence to consider that the legislator is a rational one.

12 Positive law does not bind interpretation merely to formal legality; rather, the interpretation and application of legal norms are subordinated to their substantive purpose. Law is qualified by respect for the basic values of a democratic society and also measures the application of legal norms by these values. Constitutional Court of the Czech republic, judgement, PL. ÚS 19/93 of 21 December 1993.

13 For doctrinal interpretation of the issue in question see WRÓBLEWSKI, J.: The judicial application of Law. Dordrecht, Boston: Kluwer Academic Publishers, 1992, 357 pgs. or KÜHN, Z.: Aplikace práva ve složitých prŕípadech. K úloze právních principo̊ v judikaturě. Praha: Karolinum, 2002, p. 41 ff.

14 The clear does not have to be interpreted and Interpretation ends there, where it is clear. 
legal interpretation and systematic method as well. When understood in the second meaning, the legal norm has to be interpreted in the light of lex superior - the constitutional order, thus preserving the axiological coherence of the decision-making process with the constitutional system of values (material core of the constitution). Only then may one consider the rendered decision to be legal, legitimate and fair at the same time. These cases are, however, quite rare and need to be addressed with sufficient caution in order to prevent the legal order from destabilization and its substitution by arbitrary and objectively unfair judicial decisions. This model of judicial decision-making therefore requires the justification of the ruling in a hard case by diverse sources of law, including legal principles. This approach is mandatory in order to fulfill the guaranteed right to a fair trial at the constitutional level. ${ }^{15}$ However, as mentioned before, when using a principle to optimalize a legal norm, caution is mandatory and advised at the same time by the legal doctrine. Professionalism along with the moral integrity of the judge represent a guarantee for the civil society, that the society will not remain disappointed in its trust in the legal and legitimate exercise of power by a certain judge, acting on behalf of a judicial body and the judicial branch of state power.

The mentioned moral integrity is a highly abstract term, ranging to different normative systems (other than law). Even despite the absence of a legal definition, it expresses the close relationship between the law and moral rules (standards), which should optimalize societal behaviour. The highest category of morality is good, but it has to be stated that "morality differs from law also in the fact, that it is a kind of internal order, a form of internal felt liability. Its aim is the inner development of a person. ${ }^{" 16} \mathrm{~A}$ moral imperative can therefore be perceived as a strongly-felt principle, forcing a person to act under certain circumstances in a certain way. The close relation and connection between law and morality is therefore mandatory in order to achieve the voluntary subordination under the authority of law. The meaning of moral integrity can be explained with reference to the meaning of the Latin words: mores an integer.

Mores expresses a convention (custom) in social behaviour. Synonyms corresponding to the word integer include: whole, entire, complete, pure, correct, honest, just. ${ }^{17}$ One can affirm that a morally mature judge (with moral integrity) disposes with detailed knowledge of moral standards and thus their preservation in personal and professional life is naturally expected.

It can be said from the opposite point of view that a judge with moral integrity is corruptionproof, having a strong character and inner strength. If the highest category of morality is the good, this judge must be capable of, be ready and of course willing to exercise and protect it by all for this purpose authorized instruments by the state, under the concept secundum et intra legem (art. 2 of the Constitution; principle of legality). Moral and axiological coherence of the exercise of power is mandatory for reaching a high legitimacy rate of a ruling. The eligibility of morality in the legal system was recognized also according to the Roman tradition. ${ }^{18}$

The good manners closely relate to this issue, requiring the consideration of the individual and specific circumstances of every single case. The issue of good manners was also discussed by the Constitutional Court of the Czech republic in its ruling II. ÚS 544/2000 of 12 March 2001. The court

15 Some interesting rulings (from the viewpoint of sources of law used to justify them) were pointed out by M. Turčan, e. g. the reference to The Little Prince by Exupéry in the obiter dictum of the ruling of the Constitutional court of Slovak republic, PL. ÚS.13/2012-90 of 19. June 2013. MRVA, M. - TURČAN, M.: Interpretácia a argumentácia v práve. Bratislava: Wolters Kluwer, 2016, pp. 148-151.

16 OTTOVÁ, E.: Teória práva. 3rd ed. Šamorín: HEURÉKA, 2010, p. 24.

17 WHITE, J.T.: Latin-English Dictionary. For the use of junior students. Boston: GINN AND COMPANY, 1904 , p. 302.

18 One of the most legendary quotes in the legal area is Ius est ars boni et aequi - the law is the art of the good and fair. 
identified them as ethical and generally recognized principles and their obeying is often ensured under the sanction of the legal norms. ${ }^{19}$ Referring to this legal opinion in the ruling I. US 643/04 of 6 September 2005, the court stated that good manners cannot be perceived solely as a set of moral rules used as a corrective for the exercise of subjective rights, but instead as a command for the judge to rule in accordance with equity [...], which in its consequences means the accession to the path of finding justice.

Good manners are therefore a mandatory component of the process of legal interpretation and only a morally uncorrupted judge may be prepared to reflect them in the rendered judgements. Their upholding, even at the price of ruling contra verba legis although intra legem, is in accordance with the true will of a rational legislator. The judiciary doesn't stand as an enemy towards the legislator, but instead acts as a partner prepared to cooperate in reaching a common goal - upholding the rule of law (material legal state) and the elementary principles it consists of. The reference to them in the obiter dictum part of the judgment enables the judicial authority (solely in legitimate cases) to reduce the hardness of law (the rule dura lex sed lex will not apply under these circumstances) by applying the rules of politeness. ${ }^{20}$

Even the way of a judge's private life must simultaneously adhere to the highest moral standards. It has to be stated though, that the judicial function cannot force the judge to regulate his private life in an unlimited way. Proportionality is inherent with the idea of rule of law (legal state) and therefore every requested or prescribed limitation of one's right has to be reasonable (proportional to the selected aim). The judicial function thus cannot require the judge to live a „clerical“ life. Every judge is a human being, making mistakes and however strong the effort, no one can completely adhere to the moral rules of the society throughout his life without a single breach. Excesses in behaviour thus frequently occur and it is up to the judges themselves to determine the seriousness of the act, by which the judge breached the moral norms of the society. The judges form disciplinary senates in order to address these issues whilst protecting the independent status (constitutionally guaranteed) of the judicial branch of state power. Even a slightly immoral behaviour is tolerable under certain circumstances. It is necessary that the excess in behaviour is of non-regular nature and doesn't objectively interfere with the performance of the judge's duties, leading to general loss of trust ${ }^{21}$ in the eyes of the general public which cannot be recovered.

Moral integrity must always remain closely connected with the judge's level of expertise in the field of law. Otherwise the material fulfilment of the right to a fair trial would be threatened. This right would then exist solely in a formal way - as a form without its inner content. From the formal sources of law the law would not be transformed to the area of societal relationships - the material sources of law.

\subsection{Judge's communication competence}

Even if the judge was a perfect lawyer knowing the law and the methods of its interpretation and also an honest, moral person, it would not be sufficient. In order to guarantee justice, the judge also has to have some skills for conducting the court proceedings. Especially the competence to communicate

19 Paragraph 10c of the Act no. 233/1995 Coll. - Executor's Code could serve as an example.

20 Ruling of the Constitutional Court of the Czech republic I. ÚS 643/04 of 06. September 2005. See also MRVA, M: Dobré mravy v judikatúre contra legem s ohladom na princíp právnej istoty. In: Vybrané aspekty súdneho precedensu v podmienkach Slovenskej republiky. Bratislava: Univerzita Komenského v Bratislave, Právnická fakulta, 2013, pp. 66-79.

21 Trust in the fairness and legitimacy of the rendered judicial decisions. 
with the parties of the dispute and its representatives as well as with other persons interested in the proceedings (e.g. witnesses), both oral (in the proceedings) and written (in the decisions).

To the written communication of the courts in relation to the parties of the dispute the amount of legal literature is devoted, mostly dealing with the problem of proper and persuasive reasoning of the judicial decisions. The courts are obliged to render persuasive decisions, i.e. decisions with premises and conclusions resulting from these premises which are acceptable, rational and deemed as fair by broader juristic (but also laic) public. ${ }^{22}$ The decision must contain a brief and clear description of issues of fact, evaluation of performed evidence and consolidation of issues of fact reached by the court. In the reasoning, the court also has to explain why it did not take into consideration certain facts, respectively why it considered these to be irrelevant or not corresponding with the reality. Furthermore, the court has to state the legal qualification of the issue, the procedural defence of the party of the proceedings and reflect also the jurisprudence (if existing). Of course, the necessity to mention the rational consideration leading to the judgment cannot be omitted. From the reasoning, it must be evident why the court decided in the way it did. It is inadmissible that the reasoning contained the solution of personal problems or conflicts between judges or representatives of the parties in the dispute. The decision cannot in any case contain an insult or criticism of the subordinate court or the representatives or even the parties in the dispute. Such a content of the reasoning would be a demonstration of the lack of professionalism of the judge and would also have a negative impact on the persuasiveness of the decision and thus on justice itself.

Equally important is the communicative competence of the judge consisting in the oral communication with the parties in the dispute, their representatives and other persons involved in the proceedings. This competence is realized during the proceedings (or by conducting other judicial actions such preliminary examination, search of premises, etc.). The judge who should be capable of persuading the parties about fairness of the judicial decision and also the proceedings itself has to be able to properly communicate with the parties in the dispute. This skill is demonstrated in the communication which is adequate to the intelligence, age, but also emotional state of the party in the dispute. The judge cannot address the party with disdain regardless of its social statute, education, age, ability to understand the conduct of the proceedings, etc.; if the judge fails in this role, the party has necessarily an impression that it is not impartial. In such a situation no one can persuade the party about the fairness and justice of the decision in the case. Therefore, the judge has to communicate with the parties in the dispute in a clear, rational and tactful manner. It is absolutely inadmissible for the judge to look down on the parties. The judge represents the court in the particular case and has to be therefore authoritative. It does not, however, mean snobby.

Furthermore, the judge must be able to communicate properly also with the representatives of the parties in the dispute. His role is not to solve personal problems with them during the proceedings, he must remain neutral. Nevertheless, it does not mean that he cannot guide them when they behave in an improper or rude manner or when their expression is not relevant.

Last but not least, we cannot omit the importance of the communication of the judge with other persons involved in the proceedings (especially witnesses and authorized experts) who are present in the proceedings only at a certain point. In the communication with them, the judge has to behave in the manner not to raise any doubts about his impartiality and independence, especially towards parties in the dispute. Especially by asking questions, he has to be distant and eliminate suggestive and captious questions and also questions irrelevant to the merit of the case.

22 VRCHA, P.: Odůvodnění civilního rozsudku. 2nd ed. Praha: Leges, 2016, p. 64. 
There is no general rule applicable to all persons mentioned above. The judge must be polite and tactful which requires communication competence consisting in the ability to adapt the rules of social intercourse to every individual case, i.e. an adequacy of the judge's behaviour. The basis of this adequacy must be empathy - the judge should behave to the parties in the dispute, their representatives and other persons involved in the proceedings in the manner he would anticipate in their position in the court's proceedings. Without being tactful and communication competent (both in oral and written communication), we cannot speak about the access to justice. Even the best and most intelligent judge seeking for justice is not capable to render a decision which would be perceived by the parties in the dispute as just when he lacks the communication competence.

\subsection{The Bangalore principles of judicial conduct}

In the UN Economic and Social Council resolution ${ }^{23}$ no. 2006/23: Strengthening Basic Principles of Judicial Conduct of July $27^{\text {th }} 2006$, the UN has recognized the Bangalore principles as the advancement and amendment of the Basic Principles of the independence of the Judiciary. These are designed to provide guidance to judges and to afford the judiciary a framework for regulating judicial conduct.

The aim of the Bangalore principles ${ }^{24}$ of Judicial conduct is to strengthen the judicial integrity. They can be considered as a tool for better understanding and for the support of the role, that the independent judiciary has (plays) in all states declaring the preservation of the rule of law (the concept of legal state in the continental legal system) and its principles. The system of values protected through these principles ${ }^{25}$ include the mentioned moral integrity of the judge and his competence and diligence (professionalism). These norms of ethical conduct should moderate the conduct (behaviour) of the judges and provide the necessary direction on the path of meeting them. There are six basic values mentioned in this regard - independence, impartiality, integrity, propriety, equality, competence and diligence. The mentioned values are essential for the judge and, according to the provided legal definition, the term judge for the purposes of the The Bangalore Draft Code of Judicial Conduct 2001(adopted in 2002) means any person exercising judicial power, however designated.

The integrity along with his professional level (competence and diligence) are considered to be the core of the proper execution of judicial power which has been entrusted to the judges as individuals. Every decision-making process conducted in conformity with the monocratic principle has a sensibly higher demand for the level of moral integrity of the person conducting the process.

The judge's conduct along with the professional behaviour must reaffirm the faith of the society and its members in the integrity of the judiciary. The way a judge behaves also sensibly affects the opinion that the general public has in relation to judiciary and to the way it performs its role in the declared legal state. Even one misconduct may result in the loss of trust of the general public in the legal and legitimate execution of power by one of its branches - judicial branch of power. The judge should serve as the example of professional and moral behaviour in the civil society, guaranteeing

23 In terms of international law a resolution is considered to be a soft law norm, that is legally non-binding, however, it has relevance in legal interpretation - interpretation of the binding legal acts. KALESNÁ, K. - HRUŠKOVIČ, I. - ĎURIŠ, M.: Základy Európskeho práva. Bratislava: Univerzita Komenského v Bratislave, Právnická fakulta, 2008 , p. 103.

24 The Bangalore principles of judicial conduct (2002). In: http://www.unodc.org/pdf/crime/corruption/ judicial_group/ Bangalore_principles.pdf

25 The elementary principles can be considered as the reflection (recepcion) of societal values into the normative legal system. 
the trust of the society in his office, through which the judge partially fulfils the functions of a state body in a society.

In order to meet the condition of competence and diligence, the judge is required to take reasonable steps to maintain and enhance his knowledge, skills and personal qualities necessary for the proper performance of judicial duties. A requirement of great importance is to keep himself or herself informed about the relevant developments of international law, including international conventions and other instruments establishing human rights norms. That implies the essentiality of human right which are a condition of the legitimacy of the constitutional proclamation of the legal state.

Specifically, the judge is required to maintain order and decorum in all proceedings before the court and to be patient, dignified and courteous in relation to litigants, jurors, witnesses, lawyers and others with whom he or she deals in an official capacity. The judge shall require similar conduct of legal representatives, court staff and others subject to the judge's influence, direction or control. In regard to meeting the set judicial duties the judge is required to meet the conditions of effectiveness, fairness and proportionality of their acquitting in terms of time. ${ }^{26}$

\section{CONCLUSION}

The identity of the terms access to the court and access to justice depends on the guarantees of level of professionalism along with the level of moral integrity of the judge who is setting an authoritative discourse in a certain legal relationship. Only then is the judge capable of approaching the legal system in its necessary complexity and deliver an objectively fair and legitimate ruling. The legitimacy is achieved greatly by the reflection of principles, which represent the societal values fixed in the legal system. Law should serve the people and not the opposite. Therefore, legal actions and rulings should always comply with the system of moral values to the maximum extent. This goal may be achieved only if these are also known to the judge as a person endowed with the trust of the civil society in the fair exercise of power.

It is considered a legitimate expectation of the general public that the public authorities will have an interest in delivering justice to the everyday life of the civil society, thus fulfilling the ideals hidden behind the artistic depiction of the goddess Iustitia. These ideals are hidden behind the symbol of the scales, the sword, and tape and the downtrodden snake against the codex. ${ }^{27}$

Justice is the attribute of law and can be considered its core. The rule of law preserves the state of trust in law. If the trust is lost, the distrust is also applicable to the rulings and decision-making activity conducted by the courts.

An unprofessional judge without moral integrity and communication competence is not capable of providing the access to justice in a material way and thus acquire the trust of the general public. To guarantee the access to justice in a judicial proceeding, the highest possible professional and moral standards for the judges are required. The judge does not act only on behalf of the judicial branch of power, but also represents the goddess of Iustitia and its symbols in the eyes of the gen-

26 Thus guaranteeing one's right for a fair trial. A judge must therefore uphold and exemplify judicial independence in both its individual and institutional aspects (Value 1 Independence).

27 With reference to the meaning of these symbols the authors refer the reader to the study KRAJČOVIČ, M.: Nezávislost' súdnej moci z pohladu právneho princípu. In: Justičná revue, 68, 2016, č. 8-9, pp. 829-856. 
eral public. For these reason the courts have a special status among all of the public bodies, acting on behalf of the state.

\section{Bibliography:}

ČENTÉŠ, J. a kol.: Trestné právo procesné. Všeobecná čast. Šamorín: Heuréka, 2016

DRGONEC, J.: Ochrana ústavnosti Ústavným súdom Slovenskej republiky. Bratislava: EUROKÓDEX, 2010.

KALESNÁ, K. - HRUŠKOVIČ, I. - ĎURIŠ, M.: Základy Európskeho práva. Bratislava: Univerzita Komenského v Bratislave, Právnická fakulta, 2008.

KÜHN, Z.: Aplikace práva ve složitých př́padech. K úloze právních principů v judikatuře. Praha: Karolinum, 2002.

KRAJČOVIČ, M.: Nezávislost’ súdnej moci z pohladu právneho princípu. In: Justičná revue, 68, 2016, č. 8-9, pp. 829856. ISSN1335-6461.

MELZER, F.: Metodologie nalézání práva. Úvod do právní argumentace. 2nd ed. Praha: C. H. Beck, 2011. ISBN 978 80-7400-382-0.

MRVA, M: Dobré mravy v judikatúre contra legem s ohladom na princíp právnej istoty. In: Vybrané aspekty súdneho precedensu v podmienkach Slovenskej republiky. Bratislava: Univerzita Komenského v Bratislave, Právnická fakulta, 2013. ISBN 978-80-7160-362-7.

MRVA, M. - TURČAN, M.: Interpretácia a argumentácia v práve. Bratislava: Wolters Kluwer, 2016. ISBN 978-808168-390-9.

OTTOVÁ, E.: Teória práva. 3rd ed. Šamorín: HEURÉKA, 2010. ISBN 978-80-89122-59-2.

REBRO, K.: Latinské právnické výrazy a výroky. Bratislava: OBZOR, 1984.

VASILAKIS, A.: The Great Inscription of the law code of Gortyn. Heraklion: MYSTIS, 2007.

VRCHA, P.: Odůvodnění civilního rozsudku. 2nd ed. Praha: Leges, 2016.

WHITE, J.T.: Latin-English Dictionary. For the use of junior students. Boston: GINN AND COMPANY, 1904. Available at: https://archive.org/stream/latinenglishdict00whitrich\#page/n3/mode/2up.

WRÓBLEWSKI, J:: The judicial application of Law. Dordrecht, Boston: Kluwer Academic Publishers, 1992, 357 pgs.

\section{Contact information:}

JUDr. Mgr. Michal Mrva, PhD., LL.M.

michal.mrva@flaw.uniba.sk

Comenius University in Bratislava, Faculty of Law,

Department of Financial Law

Šafárikovo nám. 6

81000 Bratislava

Slovak Republic

Mgr. Michal Krajčovič

michal.krajcovic@flaw.uniba.sk

Comenius University in Bratislava, Faculty of Law,

Department of Financial Law

Šafárikovo nám. 6

81000 Bratislava

Slovak Republic 